\title{
Restoration of Forearm Supination Deformity in Brachial Plexus Birth Palsy
}

\section{Doğumsal Brakial Pleksus Paralizisinde Önkol Supinasyon Deformitesinin Restorasyonu}

\author{
Omer Berkoz ${ }^{1}$, Erol Kozanoglu ${ }^{1}$, Safiye Ozkan ${ }^{2}$, Bora Edim Akalin $^{1}$, Turker Ozkan $^{3}$
}

$1 /$ stanbul University, Istanbul Faculty of Medicine, Department of Plastic, Reconstructive and Aesthetic Surgery, Istanbul, Turkey

${ }^{2}$ Private Sector, Physiotherapy, Istanbul, Turkey

${ }^{3}$ Private Sector, Plastic Reconstructive and Aesthetic Surgery, Istanbul, Turkey Berkoz Istanbul University, to: Omer Faculty of Medicine, Department of Plastic, Reconstructive and Aesthetic Surgery, Istanbul, Turkey

e-mail: oberkoz@istanbul.edu.tr

Geliş Tarihi/Received: 23 June 2021 Kabul Tarihi/Accepted: 26 August 2021
$\ddot{O} z$

Amaç: Doğumsal brakial pleksus paralizisi sonrası gelişen önkol supinasyon deformitesi, hem fonksiyonelliğ hem de görünümü olumsuz yönde etkileyen ciddi sekellerden biridir. Supinasyon deformitesinin erken evrelerinin tedavisinde yumuşak doku girişimleri kullanılırken, geç dönemde kemik girişimlerine ihtiyaç duyulur. Bu çalışmada farklı evrelerdeki önkol supinasyon deformitelerinin restorasyonu için kullanılan yöntemler ve sonuçları incelenmiştir.

Hastalar ve Yöntem: Önkol supinasyon deformitesinin restorasyonu amacıyla opere edilen toplam 43 çocuk (ortalama yaş 8.2) çalışmaya dahil edildi. Bu hastalardan 18 tanesine yumuşak doku girişimleri, 25 tanesine kemik girişimleri uygulandı.Yumuşak doku girişimi olarak 14 hastada ise brakioradialis reroutingpronatoplasti, 4 hastada biseps re-routingprosedürü; kemik girişimleri olarak 10 hastada radius rotasyon osteotomisi, 11 hastada radius başı eksizyonuve 9 hastada distalradio-ulnarsinositoz tercih edildi. Tüm hastaların ameliyat öncesi ve sonrası aktif ve pasif önkol supinasyon ve pronasyon dereceleri goniometrik olarak ölçüldü.

Bulgular: Brakioradialis rerouting pronatoplasti ve biceps rerouting tekniği için ameliyat öncesi ve sonrası ortalama aktif pronasyon açısı sırasıyla- $32,8^{\circ}$ 'den $30,7^{\circ}$ ye ve $-40^{\circ}$ 'den $42,5^{\circ}$ ye yükselmiştir. Radius rotasyon osteotomisi, radius başı eksizyonuve distalradioulnarsinostozyapılan hastaların ameliyat öncesi ve sonrası aktif pronasyon açıları sırasıyla; $-70^{\circ}$ 'den $-4^{\circ}$ ye, $-53^{\circ}$ den $43^{\circ}$ ye, $-80^{\circ}$ den- $19^{\circ}$ ye ilerlemiştir. Sonuç: Doğumsal brakial pleksus paralizisinin geç dönem önkol sekellerinden olan supinasyon deformitesinin tedavisinde kullanılan gerek yumuşak doku gerekse de kemiğe yönelik palyatif cerrahi girişimler ile tatmin edici düzeyde fonksiyonel ve postüral düzelme elde edilebilmektedir.

Anahtar Kelimeler: Brakial pleksus, önkol, supinasyon deformitesi, tendon transferi, osteotomi \begin{abstract}
Aim: Forearm supination deformity is a serious sequela of brachial plexus birth palsy(BPBP) that affects both functionality and apperance. In the early phase, soft tissue procedures are preferred whereas bone procedures are preferred in the late phase. In this study, the techniques of forearm supination deformity restoration and their results were evaluated.

Patients and Methods: Forty three children (mean age of 8.2 years) were included in the study. Eighteen patients had soft tissue procedures and 25 patients had bone procedures. For soft tissue procedures, 14 patients had bracioradialis re-routing pronatorplasty and 4 patients had biceps re-routing procedures. For bone procedures, 10 patients had radius rotation osteotomies, 11 patients had radial head excisions and 9 patients had distal radio-ulnar synostosis. Preoperative and postoperative active and passive forearm supination and pronation degrees were measured goniometrically.

Results: The mean preoperative and postoperative active pronation degrees for brachioradialis re-routing pronatorplasty and biceps re-routing changed from $-32.8^{\circ}$ to $30.7^{\circ}$ and from $-40^{\circ}$ to $42.5^{\circ}$ respectively. The mean preoperative and postoperative active pronation degrees for radius rotation osteotomy, radial head excision and distal radio-ulnar synostosis changed from $-70^{\circ}$ to $-4^{\circ}$ and from $-53^{\circ}$ to $43^{\circ}$ and $-80^{\circ}$ to $-19^{\circ}$ respectively.

Conclusion: Satisfactory functional and postural improvements may be obtained with palliative surgeries that involve either the soft tissue or the bone in the setting of forearm supination deformities that are late sequelae of BPBP.
\end{abstract}

Key words: Brachial plexus, forearm, supination deformity, tendon transfer, osteotomy
Cite this article as: Berkoz O, Kozanoglu E, Ozkan S, Akalin BE, Ozkan T. Restoration of Forearm Supination Deformity in Brachial Plexus Birth Palsy. Selcuk Med J 2021;37(3): 193-199
Disclosure: None of the authors has a financial interest in any of the products, devices, or drugs mentioned in this article. The research was not sponsored by an outside organization. All authors have agreed to allow full access to the primary data and to allow the journal to review the data if requested. 


\section{INTRODUCTION}

Brachial plexus birth palsy is a dramatic complication that affects neonates. Most of the patients who are treated with intense physical therapy in the early period may recover sufficiently (1). However, severe sequelae with contractures and bone deformities secondary to paralysis may develop with growth in about $10 \%$ of the patients. Generally, forearm supination deformities may accompany type 2 (proximal mid-extremity) and type 4 (partially recovered total extremity) deformities (2). In all types of sequelae, an imbalance is present between the active supinator muscles (biceps brachii and supinator) and the paralytic pronator muscles (pronator teres and pronator quadratus).

The forearm supinaton deformity may be corrected passively at early stages. After 2 years of age, the interosseous membrane retracts with growth and the deformity can not be corrected passively. The interosseous membrane space narrows in the supination position of the forearm and particularly, the strong radio-ulnar fibers of the membrane retracts. In fact, the tension of these fibers blocks the pronation. The deformity becomes fixed very fastly and bending of radius and subluxation/dislocation at the distal head of ulna occur. The radial head is dislocated towards the volar side in severe cases. The dislocated distal head of the ulna may be palpated from the volar aspect of the wrist during forearm supination (2). In this study, the techniques of forearm supination deformity restoration and their results were evaluated.

\section{PATIENTS AND METHODS}

Forty three children (27 male, 16 female) between 3 and 15 years (mean age 8.2 years) who were operated at Istanbul University, Istanbul Faculty of Medicine, Department of Plastic Reconstructive and Aesthetic Surgery, Division of Hand Surgery between January 1999 and December 2006 for the restoration of forearm supination deformities were included in this study. Soft tissue interventions were performed for patients who were Stage I and II-1 according to Zancolli Classification. Biceps rerouting was preferred as a soft tissue intervention in patients whose triceps muscles were active and brachioradialis rerouting pronatorplasty was performed in patients with paralytic triceps muscles. In addition to these procedures, interosseous membrane releases were performed for patients who were Stage II-1 a and b. This release increased the range of motion of pronosupination and it prevented joint subluxation or dislocations by alleviating the contracture of the interosseous membrane

Bone procedures were performed for patients who were Stage II-2 and II-3 because distal and/or proximal radioulnar joints were affected in these patients. The ulnar head that was subluxated towards the volar side was excied in Stage II-2 patients and radioulnar fusion was performed with the forearm in 20 degrees of pronation. The ulna and the radius were positioned and their union level was detected with an appropriate angle. Then, the cortex of the radius was decorticated with a rongeur and osteosynthesis was performed. Skeletal maturation may not be completed in most of the patients and osteosynthesis was performed proximal to the growth center of the radius. Three Kirschner wires were used for osteosynthesis in all the operations. In order to strengthen the bone fixation, either cerclage with bridle wire or approximation of the joint capsule with polydioxanone sutures were performed in some patients. Also, the bone fragments that were obtained from the ulnar head were placed around the synostosis as grafts.

In radius pronation osteotomy, a horizontal radial osteotomy was performed through the intersection between the middle and distal one thirds of the radius. In fact, this area had a robust blood supply that enhanced bone healing. The forearm was positioned to have 20 degrees of pronation and the radius was osteosynthesized with either a five hole plate or three Kirschner wires. This study was approved by the Ethics Committee of our institution with the approval number June 11, 2021-12.

\section{RESULTS}

Forty three children were included in this study. Eighteen patients were Stage I and II-1 according to Zancolli Classification. Fourteen patients were Stage II-2 and 11 patients were Stage II-3 and bone procedures were performed for these patients. The stages of the patients with forearm supination deformities and the surgical procedures are summarized in Table 1.

\section{Soft Tissue Procedures}

Soft tissue interventions were performed for 18 patients. Biceps rerouting was performed in 4 patients with active triceps muscles whereas brachioradialis rerouting pronatorplasty was performed in 14 patients with paralytic triceps muscles. Interosseous membrane releases were performed in 10 patients with Stage II-1 a and b deformities.

Brachioradialis Rerouting Pronatorplasty 
Table 1. The distribution of the patients with respect to the stages and the preferred surgical procedures

\begin{tabular}{|c|c|c|}
\hline Stage & Number of Patients & Surgical Procedures \\
\hline Stage I, a & 1 & Biceps rerouting pronatorplasty \\
\hline Stage I, b & 7 & Brachioradialis rerouting pronatorplasty \\
\hline Stage $\|-1, a$ & 3 & $\begin{array}{l}\text { Biceps rerouting pronatorplasty+ } \\
\text { Interosseous membrane release }\end{array}$ \\
\hline Stage $I I-1, b$ & 7 & $\begin{array}{l}\text { Brachioradialis rerouting pronatorplasty+ } \\
\text { Interosseous membrane release }\end{array}$ \\
\hline Stage $11-2$ & 14 & $\begin{array}{l}\text { Radius pronation osteotomy }(8) \\
\text { Distal radio-ulnar synostosis }(6)\end{array}$ \\
\hline Stage II-3 & 11 & $\begin{array}{l}\text { Radius head excision (6) } \\
\text { Radius head excision+Radius pronation osteotomy ( } 2 \text { ) } \\
\text { Radius head excision+Distal radio-ulnar synostosis ( } 3 \text { ) }\end{array}$ \\
\hline
\end{tabular}

Brachioradialis rerouting was performed in 14 patients. Ten patients were male whereas 4 patients were female. The mean age was 6.5 years $(4-9)$. The right extremity was affected in 8 patients whereas the left extremity was affected in 6 patients. The mean birth weight of the patients was 4313 grams (2800 - 5500 grams) and the mean follow up was 17.4 months (11 - 28 months). Additional interventions were performed in 10 patients at the same session. In fact, wrist extension, finger extension and thumb abduction and extension were restored in 7,2 and 8 patients respectively. Additional interventions were performed at two separate anatomic regions in 7 patients and at a single anatomic region in 3 patients. The interosseous membrane release was performed in 7 patients. The preoperative and postoperative pronation and supination values of the patients are summarized in Table 2.
The mean active pronation was -32.8 degrees before the operation and it increased to 30.7 degrees after the operation. The mean active pronation gain was 63.5 degrees. The mean active supination was 62 degrees before the operation and it decreased to 51 degrees after the operation. Total active movement increased from 28.5 degrees to 81.7 degrees (Table $3,4)$. The mean forearm active pronation increased by $193 \%$ and the forearm total active movement increased by $286 \%$ in this group. On the other hand, mean forearm supination decreased by $18.6 \%$.

\section{Biceps Rerouting Pronatorplasty}

Biceps rerouting pronatorplasty was performed in 4 patients. Two patients were male whereas 2 patents were female. The mean age of the patients was 9.2 years $(8-11)$ and the mean followup was 20.7 months (14 - 26 months). The right extremity was affected in 2 patients whereas the left extremity was affected in

Table 2. The preoperative and postoperative measurements of the patients who had brachioradialis rerouting pronatorplasty

\begin{tabular}{|c|c|c|c|c|c|c|c|c|c|}
\hline $\begin{array}{l}\text { Pati } \\
\text { ent }\end{array}$ & $\begin{array}{l}\text { Gen } \\
\text { der }\end{array}$ & $\begin{array}{l}\text { A } \\
\text { ge }\end{array}$ & $\begin{array}{l}\text { Follow } \\
\text { up (Mont } \\
\text { hs) }\end{array}$ & $\begin{array}{l}\text { Preoper } \\
\text { ative } \\
\text { Pronation }\end{array}$ & $\begin{array}{l}\text { Preoper } \\
\text { ative } \\
\text { Supination }\end{array}$ & $\begin{array}{l}\text { Preoper } \\
\text { ative } \\
\text { Total } \\
\text { Active } \\
\text { Movement }\end{array}$ & $\begin{array}{l}\text { Postoper } \\
\text { ative } \\
\text { Prona } \\
\text { tion }\end{array}$ & $\begin{array}{l}\text { Postoper } \\
\text { ative } \\
\text { Supina } \\
\text { tion }\end{array}$ & $\begin{array}{l}\text { Postoper } \\
\text { ative } \\
\text { Total } \\
\text { Active } \\
\text { Movement }\end{array}$ \\
\hline 1 & $M$ & 7 & 14 & -30 & 55 & 25 & 30 & 70 & 100 \\
\hline 2 & M & 6 & 26 & -80 & 80 & 0 & -20 & 50 & 30 \\
\hline 3 & $\mathrm{~F}$ & 7 & 13 & -90 & 90 & 0 & -10 & 85 & 75 \\
\hline 4 & M & 8 & 22 & -90 & 90 & 0 & -10 & 50 & 40 \\
\hline 5 & M & 4 & 16 & -60 & 70 & 10 & 40 & 80 & 120 \\
\hline 6 & M & 8 & 17 & 10 & 30 & 20 & 35 & 50 & 85 \\
\hline 7 & M & 7 & 19 & 0 & 20 & 20 & 30 & 20 & 50 \\
\hline 8 & M & 6 & 13 & -20 & 35 & 15 & 35 & 40 & 75 \\
\hline 9 & M & 6 & 22 & -90 & 90 & 0 & 75 & -10 & 65 \\
\hline 10 & $\mathrm{~F}$ & 7 & 12 & 50 & 70 & 120 & 50 & 70 & 120 \\
\hline 11 & M & 4 & 11 & -20 & 70 & 50 & 50 & 40 & 90 \\
\hline 12 & $\mathrm{~F}$ & 5 & 19 & -40 & 70 & 30 & 35 & 60 & 95 \\
\hline 13 & $\mathrm{~F}$ & 9 & 12 & -20 & 50 & 30 & 30 & 50 & 80 \\
\hline 14 & M & 7 & 28 & 20 & 60 & 80 & 60 & 60 & 120 \\
\hline
\end{tabular}


Table 3. Total active movement values of the forearm before and after the operation

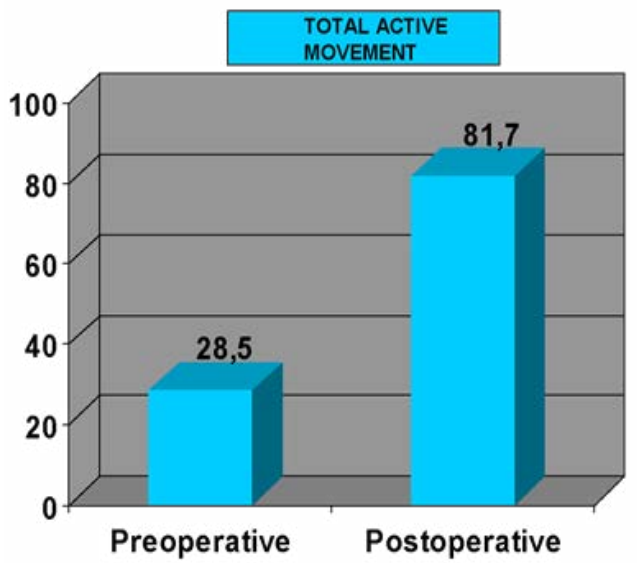

Table 4. Active pronation and supination values before and after the operation

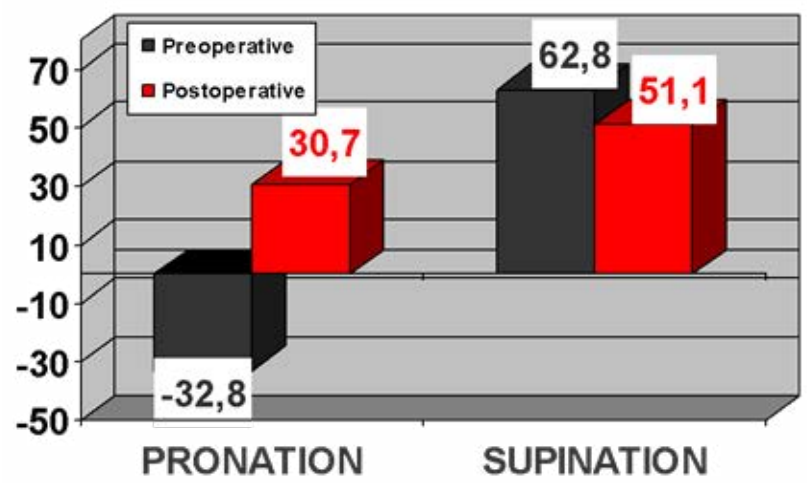

Table 5. The preoperative and postoperative measurements of the patients who had biceps rerouting procedure

\begin{tabular}{lllllllll}
\hline $\begin{array}{l}\text { Pati } \\
\text { ent }\end{array}$ & $\begin{array}{l}\text { Gen } \\
\text { der }\end{array}$ & $\begin{array}{l}\text { A } \\
\text { ge }\end{array}$ & $\begin{array}{l}\text { Follow } \\
\text { up (Mon } \\
\text { ths) }\end{array}$ & $\begin{array}{l}\text { Preoper } \\
\text { ative } \\
\text { Prona } \\
\text { tion }\end{array}$ & $\begin{array}{l}\text { Preoper } \\
\text { ative } \\
\text { Supin } \\
\text { ation }\end{array}$ & $\begin{array}{l}\text { Preoper } \\
\text { ative } \\
\text { Total } \\
\text { Active }\end{array}$ & $\begin{array}{l}\text { Postoper } \\
\text { ative } \\
\text { Prona } \\
\text { tion } \\
\text { Move } \\
\text { ment }\end{array}$ & $\begin{array}{l}\text { Postoper } \\
\text { ative } \\
\text { Supina } \\
\text { tion }\end{array}$ \\
\hline 1 & & & & & & $\begin{array}{l}\text { Postoper } \\
\text { Total } \\
\text { Active } \\
\text { Move } \\
\text { ment }\end{array}$ \\
2 & M & 9 & 26 & -80 & 80 & 0 & -20 & 30 \\
3 & M & 11 & 21 & -90 & 90 & 0 & -10 & 75 \\
4 & F & 9 & 22 & -90 & 90 & 0 & -10 & 50 \\
\hline
\end{tabular}

2 patients. Thumb and finger extension restorations were performed in 3 patients at the same session. Interosseous membrane release was performed in 3 patients. The preoperative and postoperative pronation and supination measurements are summarized in Table 5.

Table 6. Total active movement and active pronation values before and after the operation

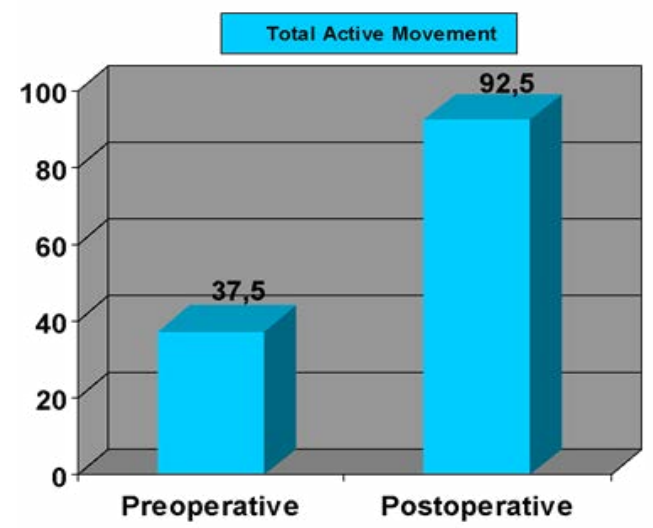

The mean active pronation was -40 degrees before the operation and it increased to 42.5 degrees after the operation. The mean active pronation gain was 82.5 degrees. The mean active supination was 77.5 degrees before the operation and it decreased to 55 degrees after the operation. Total active movement

Table 7. Total active movement and active pronation values before and after the operation

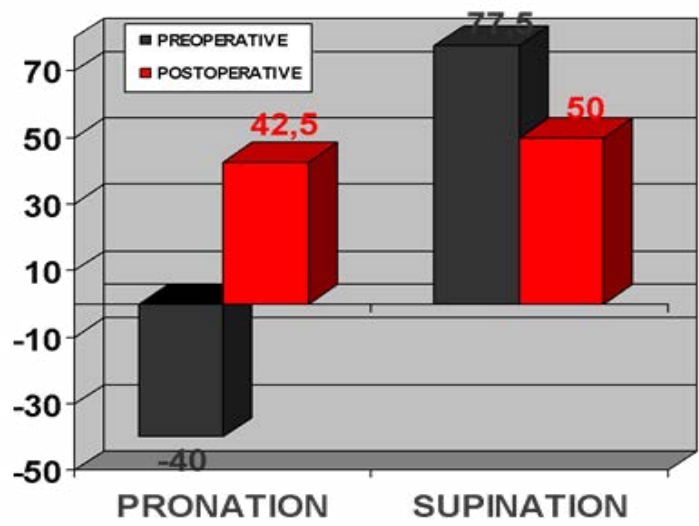


increased from 37.5 degrees to 92.5 degrees (Table $6,7)$.

\section{Bone Procedures}

Bone procedures were performed in 25 cases who were Stage II-2 and II-3 according to the Zancolli Classification. In fact, the distal and/or proximal radioulnar joints were affected in these patients. Fourteen patients were Stage II-2 and 8 of them had radius rotation osteotomy. Distal radioulnar synostosis procedure was performed in 6 patients. Eleven patients were Stage II-3 and the radial head was subluxated to the volar aspect at the proximal radioulnar joint in all of these patients. Radial head excision was performed. However, the distal radioulnar joint was affected in patients who were Stage II-3 and additional distal radioulnar synostosis was performed in 3 patients at the same session. Radius rotation osteotomy procedures were performed in 2 patients at the same session.

\section{Distal Radioulnar Synostosis}

The preoperative mean active pronation value was -80 degrees whereas the postoperative mean active pronation value was -19 degrees. The mean active supination value decreased from 80.2 degrees to 28 degrees. The total active movement value was 0.2 degrees before the operation and it became 9 degrees after the operation. In addition to the increase in active range of motion, the forearm was positioned closer to the neutral state from a mean supination of 80 degrees. In fact, it enabled the forearm to function more effectively and the functionality of the extremity increased. Due to the postural changes, the forearm became more acceptable cosmetically. The

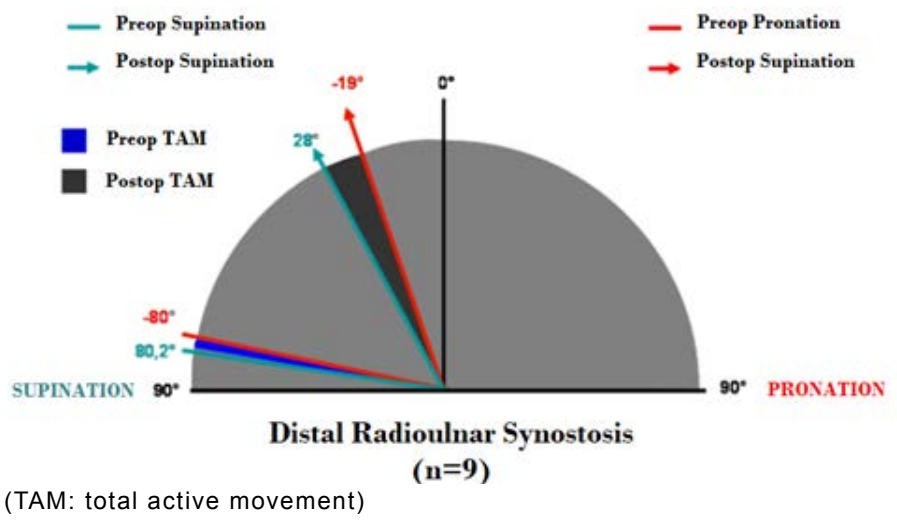

Figure 1. Forearm values before and after the distal radioulnar synostosis operation.

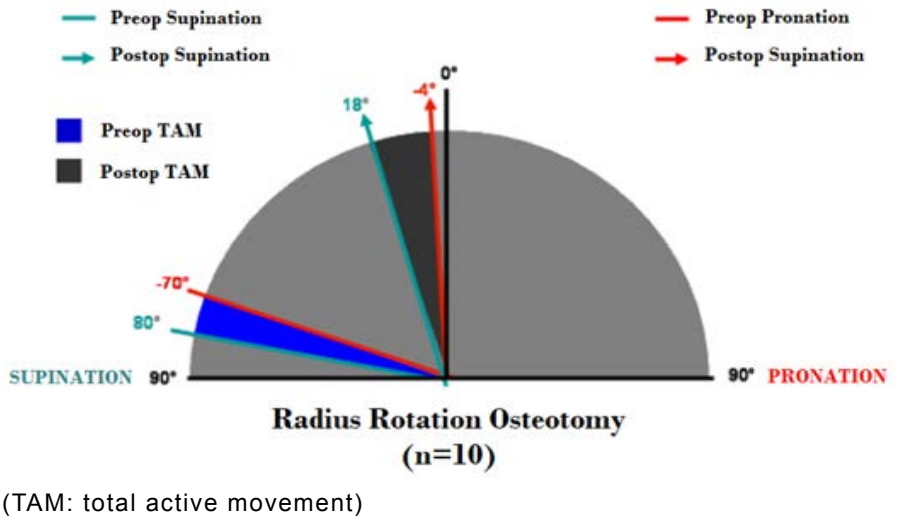

Figure 2. Forearm values before and after the radius rotation osteotomy operation.

preoperative and postoperative pronosupinatory arc of motion of the forearm are summarized in Figure 1.

\section{Radius Pronation Osteotomy}

The preoperative mean active pronation value was - 70 degrees and it was - 4 degrees after the radius pronation osteotomy. The active supination value decreased from 80 degrees to 18 degrees. The total active movement value was 10 degrees before the operation and it became 14 degrees after the operation. Also, the forearm range of motion came closer to the neutral position; in fact, it decreased from $70-80$ degrees of supination to $18-4$ degrees of supination (Figure 2).

\section{Radius Head Excision}

The preoperative mean active pronation value was -53 degrees and it was 43 degreed after the operation.

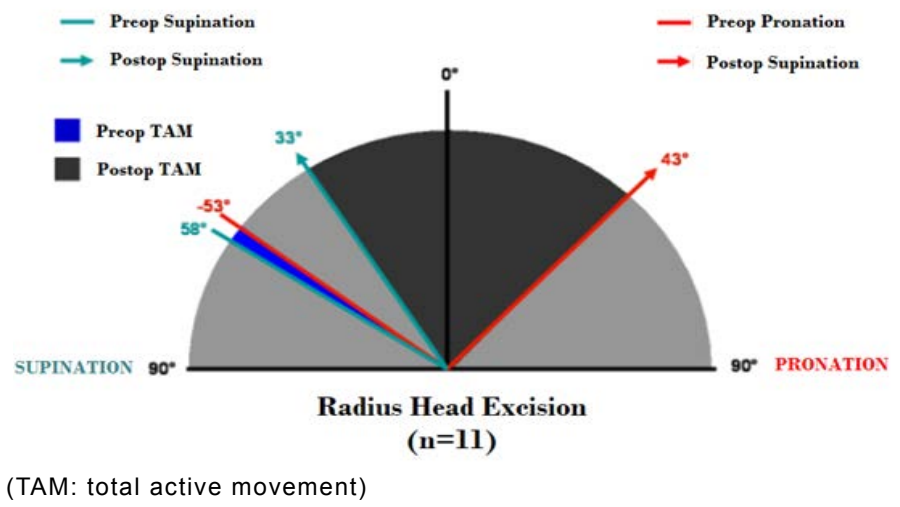

Figure 3. Forearm values before and after the radius head excision. 
The active supination value decreased from 55 degrees to 33 degrees. The total active movement value was 5 degrees before the operation and it became 76 degrees after the operation (Figure 3 ). The forearm range of motion increased dramatically in Stage II-3 patients because the volarly subluxated/ dislocated radius head was excised and the limitation of movement was alleviated at the proximal radioulnar joint. Also, radius head excision was combined with either radius rotation osteotomy or distal radioulnar joint synostosis procedures that ameliorated the function of the distal radioulnar joint.

\section{DISCUSSION}

Supination deformity of the forearm limits the hand functions severely. In the setting of this deformity, elbow flexion and shoulder abduction and internal rotation are mandatory for most of the daily activities such as wearing, eating and writing. Patients with such a deformity are reluctant to use their hands and a functional deficit is formed that is discordant with the muscle force and the sensation of the hand. In order to augment the hand functions, the deformity should be adressed in the early phase, before the formation of bone deformities and joint dislocations (1). Few techniques were described for the correction of forearm supination deformities.

Soft tissue procedures may be preferred for the treatment of mild and flexible deformities. Steindler suggested the release of supinator muscles (1) and Zancolli suggested the rerouting of the biceps tendon in conjunction with the release of the interosseous membrane (2). Radius and/or ulna osteotomies may be performed for repositioning in case of fixed deformities of the forearm. Blount described closed osteoclasis of both bones at the middle thirds of the forearm (3). Lange (4) and Zaoussis (5) performed a single ostetomy distal to the insertion of the biceps tendon at the collum of the radius and internal fixation was not required for these techniques. Lin et al. (6) preferred open radio-ulnar osteotomy with a drill and they suggested manipulation ten days after the osteotomy. Bahm and Gilbert performed open distal radius osteotomy (7). Manske et al. (8) and Gellman et al. (9) suggested percutaneous osteoclasis in conjunction with biceps rerouting. Wang et al. (10) described the single bone forearm fusion technique for severe supination deformities. Hankins and Kozin evaluated the previous techniques and they did not find satisfactory improvements in the forearm functions due to the shortcomings in the fixation of osteotomies (11). They developped a technique with the combination of proximal ulnar and distal radius osteotomies and a significant improvement and a strong fixation were maintained $(11,12)$. Kozin reported a mean improvement value of $86^{\circ}\left(45^{\circ}\right.$ $\left.120^{\circ}\right)$ and a mean pronation angle of $10^{\circ}\left(0-30^{\circ}\right)$ in patients who had combined proximal ulna and distal radius osteotomy (12). At the end of the mean followup period of 15.7 months $\left(6-33\right.$ months), a mean of $2^{\circ}$ of forearm pronation was detected during the resting position. In fact, a slight loss of pronation of $7^{\circ}$ to $17.5^{\circ}$ was detected postoperatively. However, both the patients and the families were satisfied with both the appearance of the forearm and the performance in daily activities (12). In the case series of Allende et al., there were 66 patients who had supination deformities due to brachial plexus birth palsy. Forty four patients had radius rotation osteotomy and 22 patients had soft tissue procedures such as biceps tendon rerouting with or without interosseous membrane release (13). In the osteotomy group, the mean preoperative forearm supination angle was $31^{\circ}$; it was $114^{\circ}$ at the immediate postoperative period and it was $92^{\circ}$ at the end of the followup period. There was a statistically significant difference between these values; however, no significant difference was detected between the immediate postoperative period and the end of the followup period for soft tissue procedures. Also, neither of the procedures affected the shoulder functions and both of them decreased the elbow extension angles. Wrist and finger extension increased in both groups. Preoperative parameters such as range of motion of the forearm, the condition of the proximal and distal radio-ulnar joints, the function of the triceps muscles and deformities of the shoulder and elbow and hand functions should be evaluated before the selection of the surgical procedure (13). According to Allende et al., only biceps rerouting procedure would be feasible in passively pronating forearms and additional interosseous membrane release would be required in mild and moderate soft tissue retractions with a passive motion more than $50^{\circ}$ and without joint dislocations (13). In osseous deformities with fixed contractures that had a passive forearm pronation of less than $50^{\circ}$, radius osteotomy was suggested (13). If the patients had a severe shoulder deformity, it was corrected before the forearm operations. Mild and moderate elbow flexion contractures were not regarded as contrindications of the forearm procedures in patients with supination deformities.

All forearm procedures can be performed in 
patients with active wrist extension or with a treatable wrist dysfunction. Such wrist conditions may be restored with an additional tendon transfer either before or during the forearm procedures. Otherwise, if the supinating forearm is corrected to the pronation position, the hand will drop and it will have a radial nerve palsy posture without an active wrist extension (7).

Currently, biceps rerouting with interosseous membrane release is one of the most preferred techniques in flexible forearm supination deformities (7). This procedure may be preferred for the maintenance of active pronation in the early phase and for the correction of the deformity. Biceps rerouting should be avoided in patients with triceps muscle paralysis because it would result in elbow flexion contracture. Also, this technique can not be performed in patients with radial head resections. In flexible deformities (Stage I b) with paralytic triceps muscles and in fixed deformities with adequate distal radio-ulnar joint and with a paralytic triceps muscle (Stage II-1, b), biceps rerouting procedure should not be performed. In fact, it would result in elbow flexion contractures in the late postoperative term (7). In this study, brachioradialis rerouting pronatorplasty was found to be effective in the restoration of active forearm pronation in patients with early phase supination deformities with paralytic triceps muscles (Stage I b and Stage II-1, b) (14). The elbow flexion was not affected in these patients and active forearm pronation was achieved without elbow flexion contractures. Although successful results of primary nerve surgery are being reported, such a treatment is not performed in underdevelopped settings (7). Also, there are patients who can not complete their postoperative physical therapy regimen and who can not achieve a full recovery after primary nerve surgery. According to the results of this study, palliative surgery of the late term will always be valid with its contribution in the function and the postural cosmesis of the extremity.

In conclusion, a thourough physical examination and planning are mandatory for augmenting the function of the upper extremity and for improving its cosmesis in late term BPBP sequelae before the surgery. Multistaged surgical procedures may be preferred according to the type and severity of the lesion and age and motivation of the patient.

Conflict of interest: Authors declare that there is no conflict of interest between the authors of the article.

Financial conflict of interest: Authors declare that they did not receive any financial support in this study.

Address correspondence to: Omer Berkoz, Istanbul University, Istanbul Faculty of Medicine, Department of Plastic, Reconstructive and Aesthetic Surgery, Istanbul, Turkey

e-mail: oberkoz@istanbul.edu.tr

Mobile Phone Number: 05332149305

\section{REFERENCES}

1. Raducha JE, Cohen B, Blood T, et al. A review of brachial plexus birth palsy: Injury and rehabilitation. R I Med J 2017;100(11):17-21.

2. Zancolli E. Palliative surgery: Pronosupination in obstetrical palsy. In: Gilbert A, ed. Brachial plexus injuries. London: Martin Dunitz, 2001. p. 275-91.

3. Kozin SH. Treatment of the supination deformity in the pediatric brachial plexus patient. Techniques in Hand \& Upper Extremity Surgery 2006;10(2):87-95.

4. Metsaars W, Nagels J, Pijls B, et al. Treatment of supination deformity for obstetric brachial plexus injury: A systematic review and meta-analysis. J Hand Surg Am 2014;39(10):194858. e2.

5. Lin HH, Strecker WB, Manske PR, et al. A surgical technique of radioulnar osteoclasis to correct severe forearm rotation deformities. J Pediatric Orthopedics 1995;15(1):53- 8.

6. Bahm J, Gilbert A. Surgical correction of supination deformity in children with obstetric brachial plexus palsy. J Hand Surg 2002;27(1):20-3.

7. Manske PR, McCarroll Jr HR, Hale R. Biceps tendon rerouting and percutaneous osteoclasis in the treatment of supination deformity in obstetrical palsy. J Hand Surg 1980;5(2):153-9.

8. Gellman H, Kan D, Waters RL, et al. Rerouting of the biceps brachii for paralytic supination contracture of the forearm in tetraplegia due to trauma. The $\mathrm{J}$ Bone Joint Surg Am 1994;76(3):398-402.

9. Wang AA, Hutchinson DT, Coleman DA. One-bone forearm fusion for pediatric supination contracture due to neurologic deficit. J Hand Surg 2001;26(4):611-6.

10. Hankins SM, Bezwada HP, Kozin SH. Corrective osteotomies of the radius and ulna for supination contracture of the pediatric and adolescent forearm secondary to neurologic injury. J Hand Surg 2006;31(1):118-24.

11. Allende CA, Gilbert A. Forearm supination deformity after obstetric paralysis. Clinical Orthopaedics and Related Research 2004;426:206-11.

12 Ozkan T, Aydin A, Ozer K, et al. A surgical technique for pediatric forearm pronation: Brachioradialis rerouting with interosseous membrane release. J Hand Surg 2004;29(1):227. 